九州大学学術情報リポジトリ

Kyushu University Institutional Repository

\title{
Cognizance on Pandemic Corona Virus Infectious Disease (COVID-19) by using Statistical Technique: A Study and Analysis
}

Vijay K. Yadav

G. L. Bajaj Institute of Technology and Management, Greater Noida (U.P)

Vinod Kumar Yadav

G. L. Bajaj Institute of Technology and Management, Greater Noida (U.P)

J. P. Yadav

C. S. A. University of Agriculture \&Technology, Kanpur (Etawah Campus) U.P

https://doi.org/10.5109/4068611

出版情報：Evergreen. 7 (3)，pp.329-335，2020-09. 九州大学グリーンテクノロジー研究教育センター バージョン：

権利関係 : 


\title{
Cognizance on Pandemic Corona Virus Infectious Disease (COVID-19) by using Statistical Technique: A Study and Analysis
}

\author{
Vijay K. Yadav ${ }^{1}$, ${ }^{*}$ Vinod Kumar Yadav ${ }^{1, *}$, J. P. Yadav ${ }^{2}$ \\ ${ }^{1}$ G. L. Bajaj Institute of Technology and Management, Greater Noida (U.P) India. \\ ${ }^{2}$ C. S. A. University of Agriculture \&Technology, Kanpur (Etawah Campus) U.P. India. \\ *Author to whom correspondence should be addressed: \\ E-mail: vinod.yadav@glbitm.ac.in
}

(Received June 11, 2020; Revised July 29, 2020; accepted July 29, 2020).

\begin{abstract}
As per the World Health Organization (WHO), till May 16, 2020, about 4.4 million cases of Novel Corona virus (Covid-19) infections have been reported worldwide. As a part of corrective measures to prevent the spreading of this infectious virus, a statistical analysis of transferal behavior of Covid-19 is necessary. In this work, a comparative study of the spreading trends of Covid-19 in India and USA is presented. For investigating the trends of Covid-19 pandemic spread in India and USA, a statistical model based on Least Square Method (LSM) is proposed. The parameters affecting the spread pattern and steeper rise in Covid-19 graph is discussed in detail. From the trend line predictions, using LSM, it is observed that the spread pattern follows a second degree polynomial for India as well as USA. In addition, the numerical results revealed in the present work agree well with the actual spray pattern of the Covid-19 pandemic for both countries. The results also showed that the early stage spread rate of Covid-19 pandemic in India is very less as compared to USA due to the adoption of precautionary measures at the beginning of the pandemic spread.
\end{abstract}

Keywords: COVID-19, Novel corona virus, Pandemic, Statistical technique, Trend analysis.

\section{Introduction}

Nature is more powerful than anything existing in the Universe. It has its own way to correct and save itself from the imbalance that disturbs the ecology evolution due to human interventions. Nobody knew that a trivial tiny little virus (Covid-19), weighing around $10^{-10} \mathrm{mg}$, with no color, no smell, and unseen with necked eyes is so powerful to destroy entire human race without any sound or big bang. This virus has challenged the developments of humans in just 14 days of its start. As on May 16, 2020, more than 4.0 million cases and 3 lakh deaths have been reported worldwide to World Health Organization ${ }^{11}$. The worldwide infected countries by Covid-19 as on May 16, 2020, are shown in Figure 1. Even astrological experts forecasting the future difficulties could not predict corona, a powerful weapon, escaping all radars that human has ever developed. The Covid-19 is so smartly mutating its structure that none of the climate (hot or cold), or any therapy or drugs are effective on it. Rather, symptomatic treatments like physical distancing and immunity enhancement is only the solution available at this stage.

Precautions like physical distancing is capable of reducing the COVID-19 spread, but results in huge loss in terms of country's economy. Some of the major challenges for public health include development of vaccines, remedial treatment and bridging the gaps between scientific knowledge related with human immunity, pathogenesis and spread ${ }^{2,3)}$.

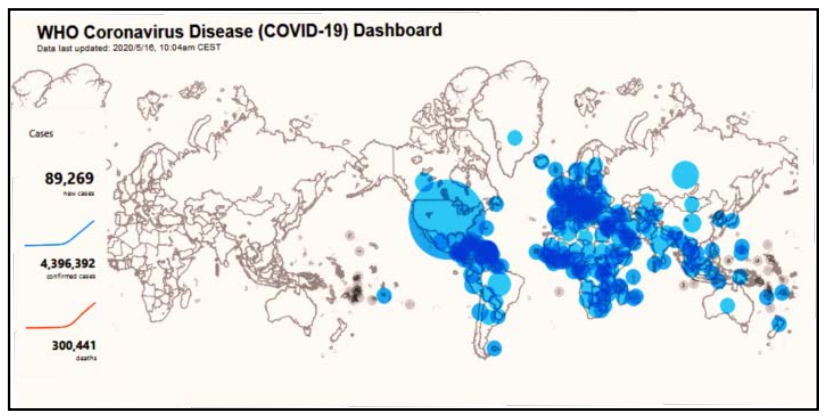

Fig. 1: Colored region are the Covid-19 infected countries in the World as on 16 May 2020 (Source: WHO).

The Covid-19 has badly impacted rural lives and livelihoods in India due to disrupted markets and farm prices, supply chains, slowdown and shortages, farmer's health, the farm work force, worker safety and personal 
protective equipment. In India, time to time advisory by central, state, health institutions and line departments have been issued and promulgated widely to protect farmers, stranded labors, and all victims through financial aid and support to defeat the Covid-19 pandemic.

The Covid-19 has alarmed the world that if human interventions are not stopped, the nature will take its own course to balance the ecology and eco system as of now no one is untouched. Covid-19 has provided an opportunity to relook on hygiene, trade, protection equipment, food, re-engineering for a new world after its halt. All the researchers, scientist, doctors, engineers, environmentalists and all answerable ones to re-think how to improve existing hygiene, sustainability, communication, transport, mental health and a new way to people work are under huge pressure to develop sustainable solutions for such pandemic. The latest statement issued by Naftali Bennett, Israeli Defense Minister, claims that the scientists of biological research institute, Israel have made a "significant breakthrough" by developing an antibody for Covid-19. Although it is in testing phase and after patenting, it will be mass produced $^{4)}$.

India has progressed beginning from ship to mouth with begging bowls, leadership willpower, and scientific input from imminent personalities like Dr. Norman E. Borlaug of CIMMYT Mexico (International Maize and Wheat Improvement Centre), C. Subramaniam, Union Agriculture Minister, Dr. M.S. Swaminathan, DG ICAR, Scientist of Agriculture Research System (ICAR \& SAUs), millions of enterprising farmers, supply chain functionaries, fertilizer industries resulting into green revolution and self-sufficiency in food production. Still, the country is facing problem of excess production and insufficient storage and difficult distribution system to meet the need of poor people while sizeable portion of food grain is wasted. India need to effectively manage with post production technology and efficient distribution system so that no one goes hungry and malnourished. The following areas need to be carefully dealt to ensure the development of reliable solutions to get rid of Covid-19 pandemic:

(a) Timely conduction of farming operations likes seeding, planting and harvesting through suitable mechanization.

(b) Post production-clean-graded-processed-packed product for marketing (especially cereals, pulses, oilseeds).

(c) Rural storage/cold storage countrywide infrastructure to handle FMCG demands of the nation.

(d) In spite of highest milk production in the world, low per capita availability needs to be balanced through proper distribution and utilization ${ }^{5}$.

(e) Through improved breeding, feeding and management aspects as per preproduction strategy- need enhancement.

(f) Fruit/vegetable processing, grading, packing, and marketing needs latest developments to handle the market requirements.

Few research articles, based on mathematical analysis, related to prediction and analysis of spray pattern of Covid-19, are presented so far. Anastassopoulouet al. ${ }^{6)}$ forecasted three-week spreading behavior of Covid-19 using time-series analysis of epidemiological data. Zhaobet al. ${ }^{7)}$ proposed a data based method to predict, control and prevent the epidemic. Alizadehet al. ${ }^{8)}$ discussed the transmission trends of Covid-19 that was originated from China to other countries of the world. Verity et al. ${ }^{9)}$ analyzed the severity of Covid-19 through Bayesian Marko-Chain Monte Carlo simulation. Human behavior is studied extensively by many researchers ${ }^{10-19)}$ applying game theory in which Habibet al. ${ }^{11)}$ dealt with social dilemma.

Through rigorous literature survey of the current pandemic situation caused due to Covid-19 at global level, it has been observed that no portable solution or model has been developed so far. Any vaccine or medicine, to treat Covid-19, with 100\% confidence level, is seldom reported in the literature. The objectives of the present work are summarized as follows:

(i) To propose a mathematical model capable of the analyzing behavioral trends of Covid-19 infection spray pattern in India and USA.

(ii) To identify the parameters that significantly affects the spreading of Covid-19 pandemic.

(iii) To propose appropriate measures for controlling the spread of pandemics like Covid-19 at its early stage of development.

\section{Methodology and data assemblage}

A statistical technique, based on the principle of Least Square Method (LSM) is used to analyze and evaluate the trends of infection caused by Covid-19 in India as well as in USA. LSM, an easy to apply approach, applied over large and small population is chosen in the present work for data analysis. LSM, capable of generating the trend line for the entire time series with minimum errors, can handle non-linear data and generates best fitting curve. It forecast the behavior of the curve with minimum errors, as the sum of the positive and negative deviation is zero, and the sum of the squares of the deviations is also minimized. This method is flexible as it allows the shifting of the trend origin from one point of time to another. A Second degree polynomial is fitted to analyze and study the spreading behavior of virus as shown in equation 1 :

$$
y=a x^{2}+b x+c
$$

Where, $\mathrm{x}$ is the number of days, $\mathrm{y}$ is the number of infected person by Covid-19. Based on $\mathrm{x}, \mathrm{a}, \mathrm{b}$, and c are the parameters to be determine to ensure best fit of trend line for spread of Covid-19. Equation 1 is used to determine the values of parameters and compare them 
with the graphs plotted using actual Covid-19 data recorded from the official website of Ministry of Health and Family Welfare (MoHFW), Govt. of India ${ }^{20)}$ and Centres for Diseases Control and Prevention, USA ${ }^{21)}$. In $\mathrm{LSM}^{22)}$, to determine the values of parameters $\mathrm{a}, \mathrm{b}$ and $\mathrm{c}$, Equation 1 is written in the form of sum of square of the errors as presented in Equation 2:

$$
\mathrm{S}=\sum_{\mathrm{i}=1}^{\mathrm{n}} \mathrm{E}_{\mathrm{i}}^{2}=\sum_{\mathrm{i}=1}^{\mathrm{n}}\left(\mathrm{y}_{\mathrm{i}}-a \mathrm{x}_{\mathrm{i}}^{2}-\mathrm{bx}_{\mathrm{i}}-\mathrm{c}\right)^{2}
$$

Where, $\mathrm{S}$ is sum of the square of errors for $\mathrm{i}=1,2$, 3.......n (number of data used in present work), $E_{i}$ is the individual error for $\mathrm{i}=1,2,3 . \ldots . . . n$. Equation 2, when differentiated partially with respect to a, b and c, and equated to the zero, results into three normal equations (Equation 3, 4, and 5):

$$
\begin{aligned}
& \sum_{i=1}^{n} x_{i}^{2} y_{i}=a \sum_{i=1}^{n} x_{i}^{4}+b \sum_{i=1}^{n} x_{i}^{3}+c \sum_{i=1}^{n} x_{i}^{2} \\
& \sum_{i=1}^{n} x_{i} y_{i}=a \sum_{i=1}^{n} x_{i}^{3}+b \sum_{i=1}^{n} x_{i}^{2}+c \sum_{i=1}^{n} x_{i} \\
& \sum_{i=1}^{n} y_{i}=a \sum_{i=1}^{n} x_{i}^{2}+b \sum_{i=1}^{n} x_{i}+n c
\end{aligned}
$$

\begin{tabular}{|c|c|c|c|}
\hline \multirow{2}{*}{$\begin{array}{l}\text { S. } \\
\text { No. }\end{array}$} & \multirow{2}{*}{ Date } & \multicolumn{2}{|c|}{ No. of persons infected } \\
\hline & & India $^{20)}$ & USA $^{21)}$ \\
\hline 1 & 01-Apr-20 & 1834 & 212747 \\
\hline 2 & 02-Apr-20 & 2069 & 241626 \\
\hline 3 & 03-Apr-20 & 2547 & 274151 \\
\hline 4 & 04-Apr-20 & 3072 & 307876 \\
\hline 5 & 05-Apr-20 & 3577 & 333593 \\
\hline 6 & 06-Apr-20 & 4281 & 362952 \\
\hline 7 & 07-Apr-20 & 4789 & 393464 \\
\hline 8 & 08-Apr-20 & 5274 & 425746 \\
\hline 9 & 09-Apr-20 & 5865 & 459989 \\
\hline 10 & 10-Apr-20 & 6761 & 493567 \\
\hline 11 & 11-Apr-20 & 7529 & 525436 \\
\hline 12 & 12-Apr-20 & 8447 & 553493 \\
\hline 13 & 13-Apr-20 & 9352 & 578178 \\
\hline 14 & 14-Apr-20 & 10815 & 604165 \\
\hline 15 & 15-Apr-20 & 11933 & 633630 \\
\hline 16 & 16-Apr-20 & 12759 & 665706 \\
\hline 17 & 17-Apr-20 & 13835 & 696621 \\
\hline 18 & 18-Apr-20 & 14792 & 724705 \\
\hline 19 & 19-Apr-20 & 16116 & 750718 \\
\hline 20 & 20-Apr-20 & 17656 & 775850 \\
\hline 21 & 21-Apr-20 & 18985 & 801028 \\
\hline 22 & 22-Apr-20 & 20471 & 830274 \\
\hline 23 & 23-Apr-20 & 21700 & 862605 \\
\hline
\end{tabular}

Table 1. No. of Infected in India and USA (April-2020).

\begin{tabular}{|c|c|c|c|}
\hline \multirow{2}{*}{$\begin{array}{l}\text { S. } \\
\text { No. }\end{array}$} & \multirow{2}{*}{ Date } & \multicolumn{2}{|c|}{ No. of persons infected } \\
\hline & & India ${ }^{20)}$ & USA $^{21)}$ \\
\hline 1 & 01-May-20 & 35365 & 1095682 \\
\hline 2 & 02-May-20 & 37776 & 1126250 \\
\hline 3 & 03-May-20 & 40263 & 1151643 \\
\hline 4 & 04-May-20 & 42836 & 1172921 \\
\hline 5 & 05-May-20 & 46711 & 1195173 \\
\hline 6 & 06-Мay-20 & 49391 & 1220032 \\
\hline 7 & 07-May-20 & 52952 & 1247567 \\
\hline 8 & 08-May-20 & 56342 & 1274681 \\
\hline 9 & 09-May-20 & 59662 & 1300243 \\
\hline 10 & 10-May-20 & 62939 & 1320621 \\
\hline 11 & 11-Мay-20 & 67152 & 1338720 \\
\hline 12 & 12-May-20 & 70756 & 1360195 \\
\hline 13 & 13-May-20 & 74281 & 1380755 \\
\hline 14 & 14-May-20 & 78003 & 1407531 \\
\hline 15 & 15-May-20 & 81970 & 1432899 \\
\hline 16 & 16-May-20 & 85940 & 1457426 \\
\hline 17 & 17-May-20 & 90927 & 1477157 \\
\hline 18 & 18-May-20 & 96169 & 1498266 \\
\hline 19 & 19-May-20 & 101139 & 1517928 \\
\hline 20 & 20-Маy-20 & 106750 & 1540296 \\
\hline 21 & 21-May-20 & 112359 & 1565324 \\
\hline 22 & 22-May-20 & 118447 & 1587530 \\
\hline 23 & 23-May-20 & 125101 & 1610247 \\
\hline 24 & 24-Маy-20 & 131868 & 1630500 \\
\hline 25 & 25-Мay-20 & 138845 & 1649054 \\
\hline 26 & 26-May-20 & 145380 & 1665736 \\
\hline 27 & 27-May-20 & 151767 & 1684372 \\
\hline
\end{tabular}

\begin{tabular}{llll}
24 & 24-Apr-20 & 23452 & 898742 \\
25 & 25-Apr-20 & 24942 & 933617 \\
26 & $26-$ Apr-20 & 26917 & 960546 \\
27 & $27-A p r-20$ & 28380 & 982659 \\
28 & $28-A p r-20$ & 29974 & 1007106 \\
29 & $29-A p r-20$ & 31787 & 1033010 \\
30 & $30-A p r-20$ & 33610 & 1062844 \\
\hline
\end{tabular}

Table 2. No. of Infected in India and USA (May-2020) 


\begin{tabular}{llll}
28 & $28-M a y-20$ & 158333 & 1707388 \\
29 & $29-$ May-20 & 165799 & 1730963 \\
30 & $30-$ May-20 & 173763 & 1754779 \\
31 & $31-$ May-20 & 182143 & 1776463 \\
\hline
\end{tabular}

Using these three normal equations (3-5), the value of unknown parameters $\mathrm{a}, \mathrm{b}$, and c have been determined.

Starting from April 2020, the Covid-19 data of India are collected from the official website of Ministry of Health and Family Welfare (MoHFW), Govt. of India ${ }^{20)}$, and the data of USA are taken from the Centres for Diseases Control and Prevention, USA ${ }^{21)}$. The LSM is applied over 61 days data (with effective from April 1, 2020, to May 31, 2020), and an estimation of the infection trend line due to Covid-19 is made. Collected data of India and USA are presented in Table 1 and Table 2 for the month of April and May 2020 respectively. This period was chosen to study the effect of preventive measures like lockdown adopted by India. In India, the first lockdown was observed from March 25, 2020 to April 14, 2020, the second lockdown was observed from April 15, 2020 to May 3, 2020, the third lockdown was observed from May 4, 2020 to May 17, 2020 and fourth lockdown is observed from May 18, 2020 to May 31, 2020.

\section{Results and discussions}

Adopting the statistical method discussed in section 2, using LSM, Figure 2 and Figure 3 are plotted to represent the best fitting curve of infected persons for the month of April 2020 in India and USA respectively. The actual spray patterns of both countries are also plotted along with in same figures. The comparison of the actual Covid-19 spread pattern plot (collected from MoHFW, and Centres for Diseases Control and Prevention, USA), along with numerical results using LSM for the month of April 2020, is presented in Figure 4.

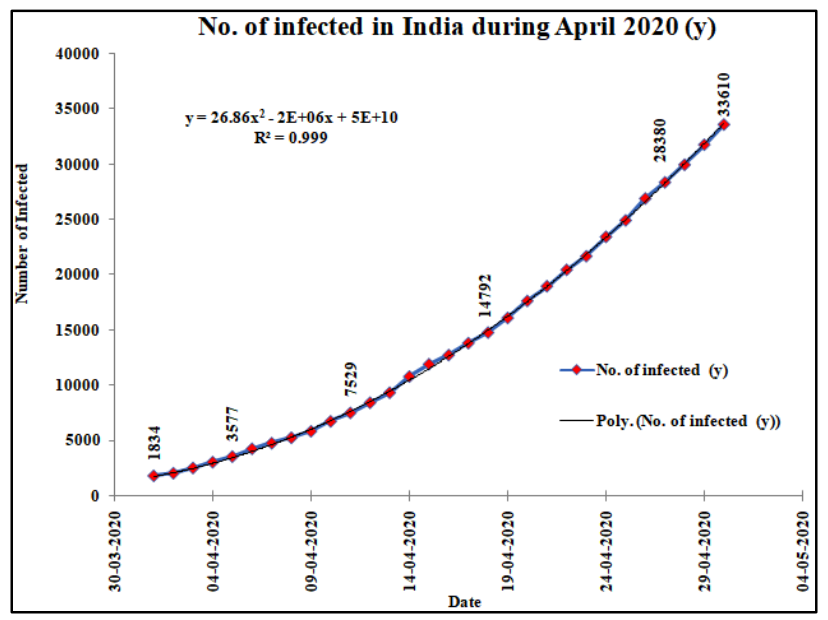

Fig. 2: Comparison of actual Covid-19 data from MoHFW and numerically predicted data for India for the month of April 2020. (Data Source for actual plot: MoHFW)
It can be observed from Figures 2-4 that the best fitted curves, drawn using LSM, are in good agreement with the actual plots. The values of parameters are obtained using normal equations 3-5. The values of the parameters for India and US are as follows: India: $\mathrm{a}=26.86, \mathrm{~b}=$ $2 \times 10^{6}, \mathrm{c}=5 \times 10^{10}$, and for USA: $\mathrm{a}=-60.29, \mathrm{~b}=5 \times 10^{6}$, $\mathrm{c}=-1 \times 10^{11}$. It is clearly visible from the Figure 2 that the slope of the curve in first week of April 2020 is less steep for India in terms of number of infected persons. A slow growing spread pattern can also be revealed from the same figure. The slope of the curve rises rapidly from second week onwards. In India, at the beginning of April 2020, the doubling rate of infection was around 5-6 days, while during third to fourth week of April 2020, the doubling rate extended to about 8-9 days. The effect of adapting lockdown can be partially reflected in the spray pattern of the virus during April 2020 in India. This is attributed to the fact that the Indian labourers have started migrating from cities to their respective villages all over India as a consequence of lockdown announced by Govt. of India. On the other hand, for USA, as can be seen from Figure 3 that the slope of the curve is increasing rapidly from start of April 2020 to the end of the month. The rate of infection of Covid-19 in USA doubled in about 7 days in the first week of April, after that, from second week onwards, this rate has extended to about 13 days. It can be inferred by seeing Figures 2 and 3 that the Covid-19 spread pattern of USA in the month of April 2020 is steeper compared to that of India. Indian Govt. has adopted the measures like complete lockdown at the early stages of the Covid-19 spread while US Govt. delayed in applying the same.

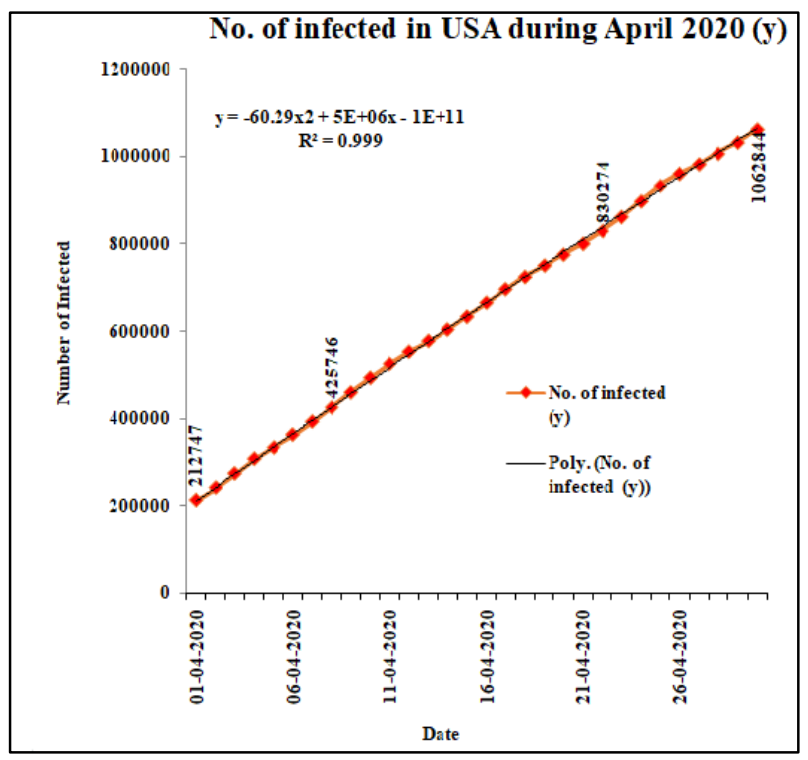

Fig. 3: Comparison of actual Covid-19 data from MoHFW and numerically predicted data for USA for the month of April 2020 (Data Source for actual plot: Centres for Diseases Control and Prevention, USA) 
Due to early lockdown in India, the people became aware at the early stages and started maintaining social distancing. In addition to lockdown and social distancing, Indian Govt. has also adopted and advised few more steps to reduce the spread of pandemic. Indians were advised to induce rich nutritious foods in their diets and do light exercises and yoga. The Indian Govt. has also launched an artificial intelligence based mobile app (Aarogya Setu) capable of tracking infected patients in close vicinity of 10 kilometres. The value of Pearson correlation coefficient $\left(\mathrm{R}^{2}\right)$ is calculated as 0.999 for India as well as USA (Figures 2 and 3). This indicates the correlation between the actual virus infected curve and trend line curve estimated by LSM is quiet close to each other. The value of $\mathrm{R}^{2}$ must lie in the range $0<$ $\mathrm{R}^{2} \leq 1$ to ensure good correlation ${ }^{23)}$. Hence, the numerically calculated data is in good agreement with the actual data. The ratios of the values of parameters of the curves estimated by the LSM for both India and USA (Figure 4) are $-0.445,0.4$, and -0.5 respectively. These values indicate an appreciable difference between the Covid-19 infection trends of India and USA. It is clearly seen from the graph that the early stage spread rate Covid-19 pandemic in India is very less as compared to USA for the month of April 2020.

The actual Covid-19 infection pattern between May 1, 2020 to May 31, 2020, for India as well USA is shown in the Figure 5 and 6 respectively. It can be observed from Figure 5 that the spray pattern of Covid-19 infection of India approximates a linearly increasing nature. The rate of doubling of infection of virus in India during first 15 days of May 2020 was recorded around 11 days, and later up to $31^{\text {st }}$ May 2020, it was reported as 9-10 days.

On the other hand, as can be seen from Figure 6, the Covid-19 infection spray pattern of USA is linearly steeper with about 10 days of doubling rate.

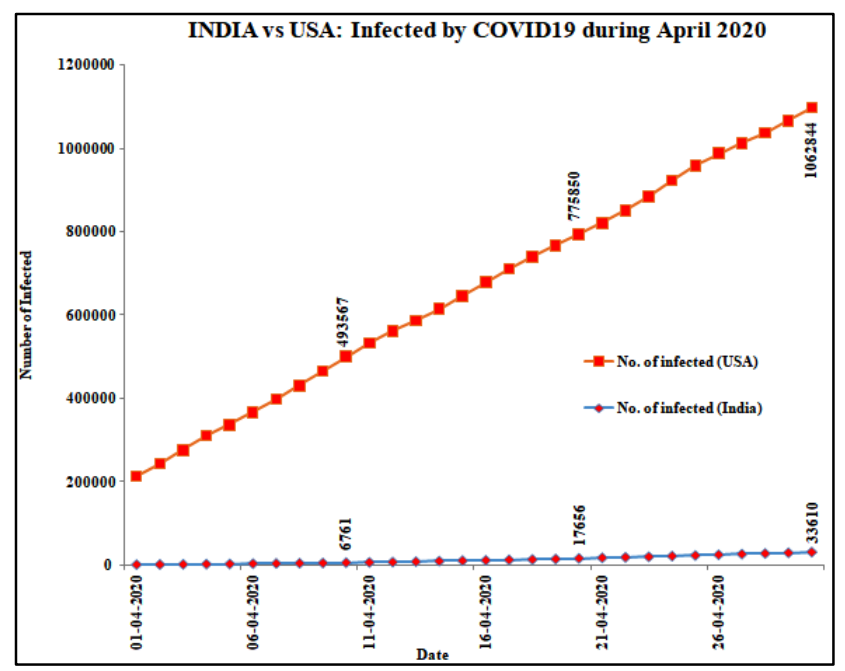

Fig. 4: Comparison of actual Covid-19 spray pattern of India and USA for the month of April 2020 (Data Source for actual plot: MoHFW, and Centres for Diseases Control and Prevention, USA)
Comparative study of the spray pattern of Covid-19 infections in India and USA is presented in Figure 7. There is huge difference in number of infected patients in India and USA till May 15, 2020. By the end of the April, USA recorded more than 10 lakh Covid-19 infections, whereas, in India it was around 35 thousand.

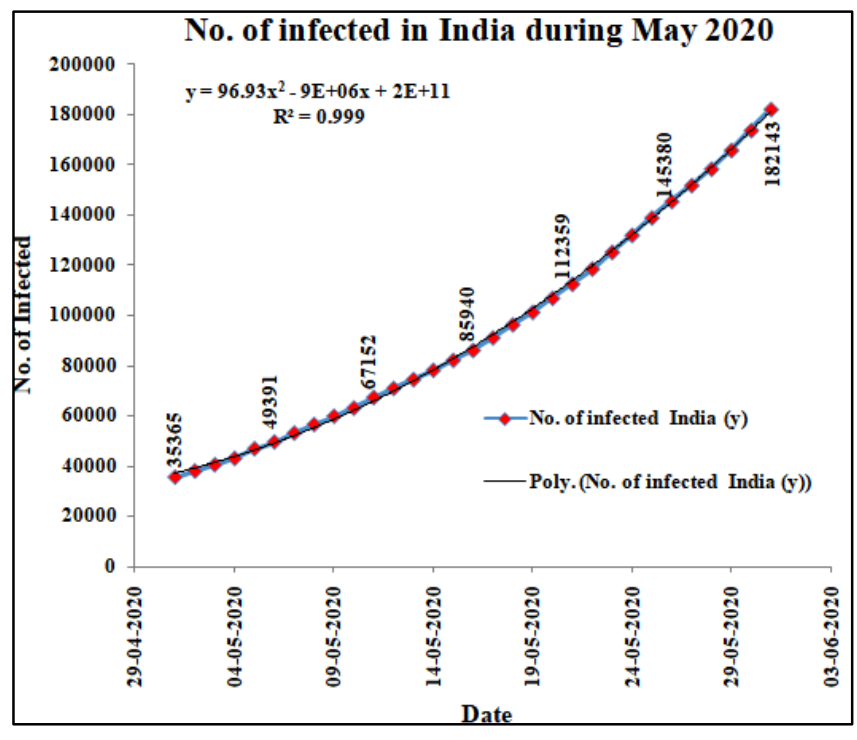

Fig. 5: Covid-19 spray pattern of India for the month of May 2020 (Data Source for actual plot: MoHFW)

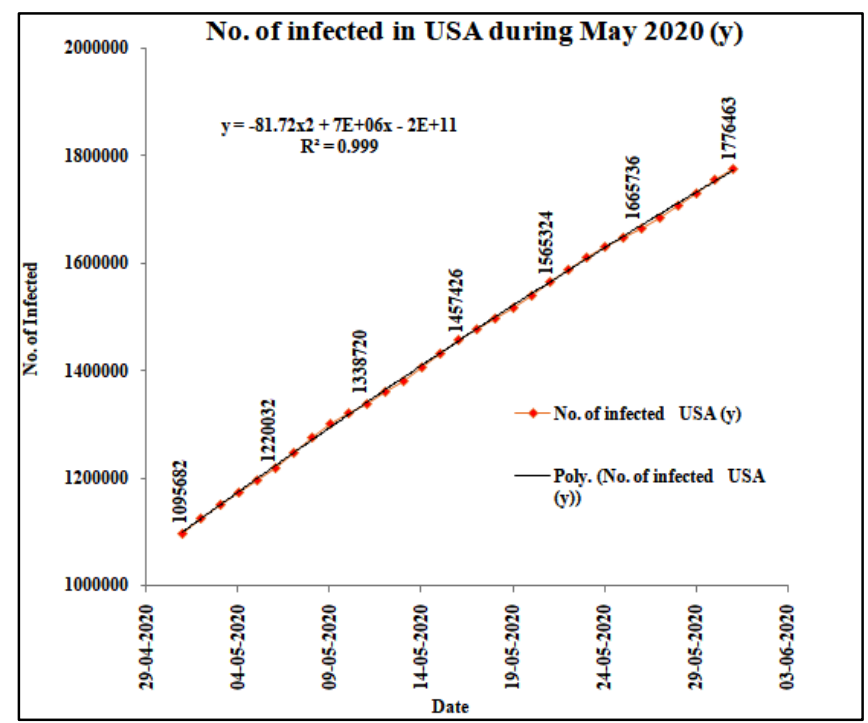

Fig. 6: Covid-19 spray pattern of USA for the month of May 2020 (Data Source Centres for Diseases Control and Prevention, USA)

The number of infected person in India on May 1, May 10, and May 20, 2020 were 35365, 62939, and 81970 respectively. On the other hand, the number of infected persons in USA on same dates was 1095682, 1320621, and 1432899 respectively. The comparative data indicates a wide difference between the numbers of infected persons. 


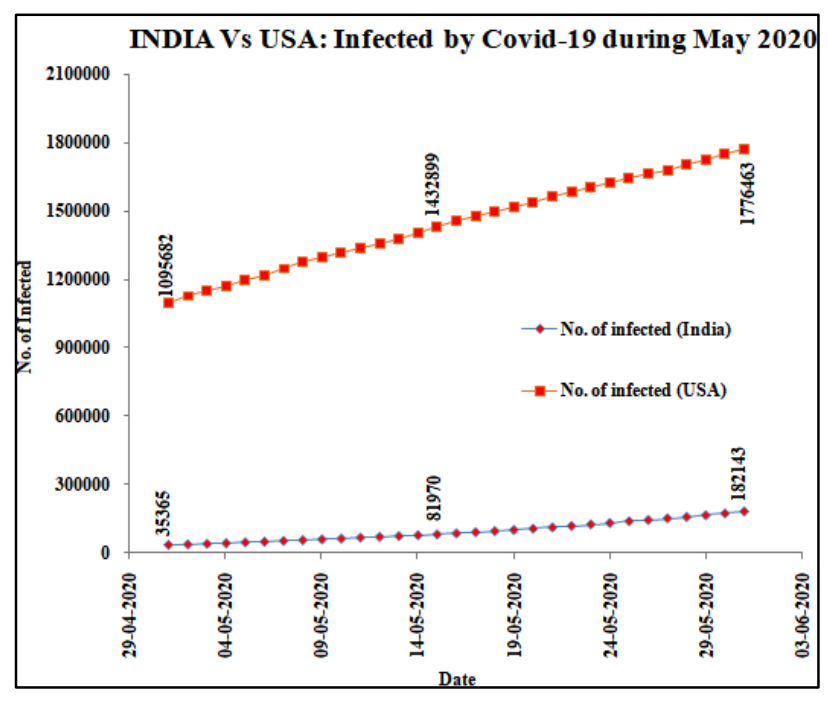

Fig. 7: Comparison of actual Covid-19 spray pattern of India and USA for the month of May 2020 (Data Source for actual plot: MoHFW, and Centres for Diseases Control and Prevention, USA). Red curve shows the infected person of USA, \& blue curve is for the number of infected in India.

In India, the first case of Covid-19 was detected on January 30, 2020 and first death of a 76 year old man, returned from Saudi-Arabia, was reported on March 12, $2020^{24)}$. In USA, the first case was detected on January 19, 2020 and first death was reported in February 2020. At the end of March 2020, about 50 states of USA got infected with Covid-19 pandemic. Since, the date of commencement of pandemic in India and USA are nearly identical, it is justifiable to compare the spread pattern of both countries. The less steep rate of Covid-19 spread has led to a serious breakthrough in India. This was undoubtedly due to the preventive measures adopted by Indians at the early stage of the pandemic spread. Paraskevis et al. ${ }^{25)}$ reported that bats may be reasons for the origination of Covid-19 virus. It has originally evolved from Central Hubei province and its capital Wuhan in the year 2019. However, till date, there are no symptoms of Covid-19 spread through bats in India.

\subsection{Novel Corona Virus (Covid-19) pandemic: Boon} or Bane.

A boon to humanity instead of curse is that the nature has refreshed itself and communicated a message among mankind to stop the excessive exploitation of the environment through various means of pollution. As a consequence of current pandemic, humans have started staying closer to their family, thereby strengthening the bond between family members. A tremendous improvement in global air quality index cannot be neglected. Furthermore, the people have started following good hygienic practices. The political opponent powerful global leaders forgot their differences to safeguard the human race in their country through several collaborative efforts. One of the brighter sides of
Covid-19 pandemic is that it has boosted entrepreneurial thinking among people. The work from home concept has positively impacted some of the businesses especially IT sectors.

Covid-19 has been blessing in disguise in many industrial sectors running in loss during lockdown periods. Millions of the wage workers in the unorganized sectors lost their jobs in a panic at one side. On the other hand, due to lockdown, many retailers and vendors of groceries, and vegetables have started earning profits by several means. The digital corporations and social media platforms acted as facilitators and multipliers of Covid-19 related misinformation and rumors by promulgating a conspiracy that Covid-19 has been intentionally developed as a means of biological war.

The global economy is under quarantine due to a lockdown situation worldwide impacting all sectors including medicine, agriculture, dairy, fisheries, transport, energy, and others. The Oxford economics has warned that a potential pandemic could lead to a reduction of 1.3 percent in global economic annual growth, equivalent to 1.1 trillion (a thousand billion) dollars in lost revenues ${ }^{26)}$.

\section{Conclusions}

In the present work, a comprehensive investigation of the spreading patterns of COVID-19 in India and USA is discussed in detail. A mathematical model, based on Least Square Method (LSM), is proposed and its results are compared with the actual spread patterns of Covid-19 pandemic. The following conclusions are drawn:

(i) The spread of the Covid-19 pandemic follows the trend of second order polynomial as on April 1, 2020 to May 31, 2020 for India as well as for USA.

(ii) Precautionary measures like lockdown, social distancing and immunity enhancement are only the possible ways of preventing the spread of the viruses like Covid-19.

(iii) The medical and engineering research need reformation to handle the emergencies caused due to unpredictable spread of viruses like Covid-19.

(iv) Although Covid-19 is extremely dangerous for mankind and but it has helped the environment to reframe its structure in some way.

\section{Acknowledgements}

The authors are thankful to, ministry of health and family welfare (MoHFW) India, and Centres for Diseases Control and Prevention, USA for uploading useful information \& Data related to Covid-19 on their website on a regular basis.

\section{Author Contributions}

All three authors have equal contribution for the finalization of this paper. 


\section{Conflict of interest}

The authors declare no conflict of interest for the work presented in this paper.

\section{References}

1) “Corona virus situation report,"https://www.who.int/emergencies/novel-coro navirus-2019/situationreport(accessed May8, 2020).

2) B. Gates, "Responding to Covid-19: a once-in-a-century pandemic,” New England Journal of Medicine., $382 \quad 1677-9 \quad$ (2020).(doi: 10.1056/NEJMp2003762).

3) M. Lipsitch, D.L. Swerdlow, L. Finelli L, "Defining the epidemiology of Covid-19:studies needed,” New England Journal of Medicine. 382 1194-6 (2020). doi: 10.1056/NEJMp2002125.

4) Effect of corona virus (NDTV News) https://www.ndtv.com/world-news/coronavirus-israe l-says-made-covid-19-antibody-that-neutralises-viru s-in-patients-body-222369.(accessed May15, 2020).

5) Ministry of food processing Industries https://www.mofpi. nic.in/ (accessed May9, 2020). Ministry of food processing Industries, New Delhi.

6) C. Anastassopoulou, L. Russo, A. Tsakris, C. Siettos, "Data-Based analysis, modelling and forecasting of the novel coronavirus (2019-NCoV) outbreak," A pre-print,February 12, 2020.

doi:https://doi.org/10.1101/2020.02.11.20022186.

7) B. Zhaob, J. Cao, "Statistical analysis on COVID-19,” Biomedical journal of technical \& scientific research., 26 (2) 2020.BJSTR. MS.ID.004310.

8) M. Alizadeh, A.H. Dehkordi, P. Derakhshan,P, Derakhshan, A. Derakhshan, "Understanding epidemic data and statistics: A case study of covid-19.PreprintMarch 2020,” (doi: 10.1101/2020.03.15.20036418).

9) R. Verity, L.C. Okell, I. Dorigatti, P. Winskill P, C. Whittaker, N. Imai, G. Cuomo-Dannenburg, H. Thompson, G.T. Walker, H. Fu, A. Dighe, J.T. Griffin, M. Baguelin, S. Bhatia, A. Boonyasiri, A. Cori, A. Cucunuba, R. FitzJohn, K. Gaythorpe, W. Green, A. Hamlet, W. Hinsley, D. Laydon, G. Nedjati-Gilani, S. Riley, S. Elsland, E. Volz E, H. Wang, Y. Wang, X. Xi, C. Donnelly, A. Ghani, N. Ferguson, "Estimates of the severity of coronavirus disease 2019: a model-based analysis," Lancet Infect Dis.2020.

10) R. Axelrod and W. D. Hamilton, "The Evolution of Cooperation,” Evolution (N.Y)., 211 (4489) 13901396 (1981).

11) MD. Ahsan Habib, K. M. Ariful Kabir, Jun Tanimoto,"Do humans play according to the game theory when facing the social dilemma situation?" A survey study,"Evergreen 7(1) 7-14(2020).
12) J.V. Neumann, and O. Morgenstern "Theory of games and economic behavior, " Princeton University Press, 1953.

13) L. Heuer and A. Orland, "Cooperation in the Prisoner's Dilemma: an experimental comparison between pure and mixed strategies,” R. Soc. Open Sci., 6 (7) 182142, (2019).

14) F. Exadaktylos, A. M. Espín, and P. Branas-Garza, "Experimental subjects are not different," Sci. Rep., 3 (1213) 1-6 (2013). (doi:https://doi.org/10.1016 /S14733099(20)30243-7).

15) M.A.Nowak, and S. Coakle, "Evolution, Games, and God: The Principle of Cooperation,". Harvard University Press, 2013.

16) J.Tanimoto ,"Evolutionary Games with Sociophysics ," Springer, 2018.

17) T.Fujisaki, "Evaluation of Green Paradox:Case Study of Japan,"Evergreen 5(4) 26-31(2018).

18) J. Tanimoto ,"Fundamentals of Evolutionary Game Theory and its Applications," Springer, 2015.

19) V. Capraro, J. J. Jordan, and D. G. Rand, "Heuristics guide the implementation of social preferences in one-shot Prisoner's Dilemma experiments," Sci. Rep., 4 1-5 (2014).

20) Ministry of health and family welfare, India. https://www.mohfw.gov.in/ (accessed May16, 2020).

21) Centres for Diseases Control and Prevention, USA. https://www.cdc.gov/coronavirus/2019-ncov/cases-u pdates/index.html(accessed May8, 2020).

22) S.J. Miller, "The Method of Least Squares, Mathematics Department Brown University, Providence: Brown University” 1-7 (2006).

23) P. Schober, C. Boer, "Correlation Coefficients: Appropriate Use and Interpretatio, Anesthesia \&Analgesia,” February 2018: Vol.126, no. 5.

24) Hindustan Times (Newspaper). 12 March 2020. (accessed March27, 2020).

25) D. Paraskevis, E.G. Kostaki, G. Magiorkinis, "Full-genome evolutionary analysis of the novel corona virus (2019-nCoV) rejects the hypothesis of emergence as a result of a recent recombination event," Infection, Genetics and Evolution (2019). https://doi.org/10.1016/j.meegid.2020.104212.

26) Covid-19 and economy https://www.eurotopics.net/ en/234743/covid-19-and-the-economy-both-curse-an d-blessing\#(accessed May17, 2020). 